\author{
Vedran Mrzljak \\ E-mail: vedran.mrzljak@riteh.hr \\ Tomislav Mrakovčić \\ E.-mail: tomislav.mrakovcic@riteh.hr \\ Faculty of Engineering Rijeka, Vukovarska 58, 51000 Rijeka
}

\title{
Comparison of COGES and Diesel-Electric Ship Propulsion Systems
}

\begin{abstract}
Diesel-electric ship propulsion is a frequent shipowners choice nowadays, especially on passenger ships. Despite many diesel engines advantages, their primary disadvantage is emission of pollutants. As environmental standards become more stringent, the question of optimal alternative to diesel-electric propulsion arises. COGES (COmbined Gas turbine Electric and Steam) propulsion system is one of the proposals for alternative propulsion system, primarily due to significant reduction of pollutant emissions. On the other hand, gas turbines have higher specific fuel consumption in comparison with diesel engines what represents their noticeable disadvantage. However, some analyzes suggested that COGES propulsion system could be still cost-effective in comparison to diesel-electric propulsion, particularly on passenger ships where higher initial investment can be compensated by increasing the number of passenger cabins. This paper shows a comparison of abovementioned propulsion systems, which can be useful for the optimal ship propulsion system selection.
\end{abstract}

Keywords: COGES, diesel-electric propulsion, emission of pollutants

\section{Introduction}

For a large number of today's passenger and cruise ships, diesel-electric propulsion was selected as optimal solution. On the other hand, other combined propulsion systems are developing rapidly and they have a goal to reduce the share of diesel-electric propulsion on these types of ships. COGES propulsion system is one of the potential candidates which must be taken into consideration during selection. Some of its features and characteristics are significantly better in comparison to diesel-electric propulsion. The main disadvantage of COGES propulsion system is operating cost and designers made some efforts of cost compensation on passenger or a cruise ships.

The general advantage of combined cycles with electric transmission is that they allow the adaptation of high-speed turning turbines to the slow turning propellers 
without the need of a heavy reduction gear. In addition, with all the generators supplying power to a common distribution system, one prime mover can easily provide power to two or more shafts and ship service. Another advantage of combined cycles with electric transmission is that the location of the main engine is less constrained compared with designs featuring a direct transmission between the engine and the propeller [1]. Further improvement can be achieved if prime mover is more compact and it's engine room use less space so additional passenger cabins could be accommodated.

This paper presents a comparison of COGES and diesel-electric propulsion systems according to their most important operating characteristics and the exploitation costs.

\section{COGES propulsion system}

\subsection{COGES propulsion system history}

Due to concerns of exhaustion of world petroleum reserves and the will to make vessels more effective, the combined cycle propulsion has been considered as an option for naval applications in the past. The naval ships are in most cases powered by gas turbines and thermal efficiency of the propulsion plant is improved by introducing heat recovery of the exhaust and a steam cycle.

COGES propulsion system for ships was firstly proposed by Mills [2] and Brady [3]. A detailed analysis of the US Navy Rankine Cycle Energy Recovery (RACER) proposal by Halkola [4] also shows COGES as an attractive propulsion system.

Ahlqvist [5] compared five different combined propulsion systems for application on a 2500 passenger cruise ship. In Shipping World and Shipbuilder [6] a number of different gas turbine plants and combined cycles plants powering a fast ferry and cruise ship were compared.

More recently, installation of COGES propulsion systems in Celebrity Cruise's ships Millennium and Infinity as well as Royal Caribbean's ship Radiance of the Seas was reported by McKesson [7] at the Seatrade Miami conference.

\subsection{COGES propulsion system overview}

COGES propulsion system is based on electric propulsion motors and alternators driven by both gas turbines and steam turbine(s). Heat recovery steam generators are fitted in the gas turbine exhaust lines and generated superheated steam (at approximately $30 \mathrm{bar}$ ) is led to a steam turbo-alternator.

COGES completely change the properties of conventional propulsion system, whereas gas turbine efficiency decreases at low load, the steam turbine recovers the loss of power. The result is constant fuel consumption over a wide operational range.

Heat for ship's services is taken directly from the steam turbine extraction or at the 
steam turbine exhaust and thus there is normally no need to fire-up auxiliary boilers. This is an important aspect in calculating total fuel consumption and overall emissions (prime movers plus boilers). Attention must be paid on the choice of steam-cycle details, such as boilers, condensers and type of cycle (condensing or back-pressure) in order to design an economically optimal plant.

Cruise ships have high heat demands and thus the boiler fuel price impact is significant. In general, consumption of heat energy needs greater attention on large cruise ship installations due to ever-increasing heat requirements, mainly for fresh water production. Compact and simple machinery as well as lower fuel consumption are the main advantages, but the sensitivity to fuel price changes remains as disadvantage.

Some authors give specifications of gas turbines which are usually installed in COGES propulsion plants [8], [9]. Moreover, it is difficult to obtain realistic data for built-in steam turbines, because COGES steam turbines are used exclusively to produce necessary ship electricity and steam turbines participate in total propulsion power output only through actual demand on the ship electrical grid. Therefore, it can be concluded that gas turbines are prime movers in the COGES propulsion systems while steam turbines are auxiliary machinery. Some examples of gas turbines installed in the COGES propulsion systems and their characteristics are given in Table 1:

Table 1.: Working parameters of gas turbines used in the combined gas and steam turbine cycle

\begin{tabular}{|c|c|c|c|c|c|}
\hline Type of turbine & $\begin{array}{c}\mathrm{N}_{\mathrm{GT}} \\
(\mathrm{kW})\end{array}$ & $\begin{array}{c}\mathrm{m}_{\mathrm{GT}} \\
(\mathrm{kg} / \mathrm{s})\end{array}$ & $\begin{array}{c}\mathrm{t}_{4} \\
\left({ }^{\circ} \mathrm{C}\right)\end{array}$ & $\begin{array}{c}\eta_{\mathrm{GT}} \\
(-)\end{array}$ & $\begin{array}{c}\mathrm{be}_{\mathrm{GT}} \\
(\mathrm{g} / \mathrm{kWh})\end{array}$ \\
\hline Siemens SGT-400 & 12900 & 39,7 & 570 & 0,340 & 248,0 \\
\hline Alstom GTX100 & 43000 & 122,0 & 546 & 0,370 & 227,9 \\
\hline Siemens GT10B & 24400 & 80,4 & 538 & 0,347 & 243,0 \\
\hline General Electric LM2500 & 22400 & 68,0 & 528 & 0,365 & 230,9 \\
\hline ABB GT35 & 17000 & 92,3 & 378 & 0,320 & 263,5 \\
\hline
\end{tabular}

Legend: $N_{G T}=$ gas turbine power; $m_{G T}=$ gas turbine mass flow rate; $t_{4}=$ temperature of the exhaust gas from the gas turbine; $\eta_{G T}=$ gas turbine efficiency; be $e_{G T}=$ gas turbine specific fuel consumption

Examples of different COGES propulsion systems layouts can be found in many papers and basic system layout is shown on Fig. 1 ([10], [11]). 


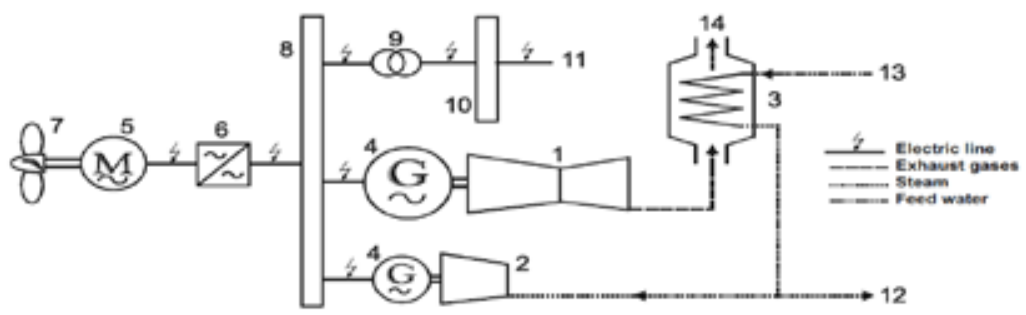

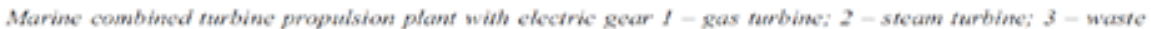
heal boiler: 4-generator: 5 - electric mofor: 6 - frevwency comerier: 7 - propeller: 8 - high voliage

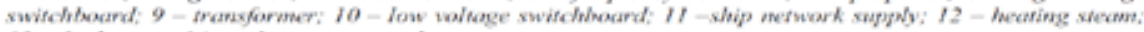
13 - feed water: $14-$ exdatest gases outlet

Fig. 1 Marine combined turbine propulsion plant with electric gear

Legend: 1 - gas turbine; 2 - steam turbine; 3 - waste heat boiler; 4 -generator; 5 - electric motor; 6 - frequency converter; 7 - propeller; 8 - high voltage switchboard; 9 - transformer; 10 - low voltage switchboard; 11 - ship network supply; 12 - heating steam; 13 - feed water; 14 - exhaust gases outlet

\section{Diesel-electric propulsion system}

\subsection{Diesel-electric propulsion system history}

After the rather experimental applications of battery driven electric propulsion at the end of the 19th century took place in Russia and Germany, the first generation electric propulsion was taken into use in the 1920's as a result of the strong competence of reducing transatlantic crossing times for passenger liners [12]. At that time, the high propulsion power demand could only be achieved by turbo-electric machinery.

With the introduction of high efficient and economically favorable diesel engines in the middle of the $20^{\text {th }}$ century, steam turbine technology and electric propulsion more or less disappeared from merchant marine vessels until the 1980's. The development of variable speed electric drives, first by the AC/DC rectifier (Silicon Controlled Rectifier - SCR) in the 1970's and the AC/AC converters in the early 1980's enabled the power plant based electric propulsion system, which is typical for the second generation of electric propulsion. A fixed voltage and frequency power plant consisting of a number of generator-sets feeding to the same network was supplying the propulsion as well as the hotel and auxiliary power. The propulsion control was done by speed control of the fixed pitch propellers (FPP). These solutions were firstly used in special vessels like survey ships and icebreakers, but also in cruise vessels.

In direct driven diesel propulsion, thrust can also be controlled by a hydraulic system varying the propeller pitch angle, what is denoted as controllable pitch propellers (CPP). Podded propulsion was introduced in early 1990's where the electric motor is installed directly on the fixed pitch propeller shaft in a submerged, rotatable pod. While 
this concept was originally developed to enhance the performance of icebreakers, it was early found to have additional benefits on hydrodynamic efficiency and maneuverability.

\subsection{Diesel-electric propulsion system overview}

This is "traditional" machinery, which in case of very high power calls for large engines. The prime movers, e.g. diesel engines, supply a power to the electric generator shaft. The electric motor, which could be the main propulsion motor, is placed in submerged, rotatable pod or drives ship's screw by line shaft [13].

In any isolated power system, the amount of generated power must be equal to the consumed power including losses. For an electric system consisting of an electric power generation plant, a distribution system, including distribution transformers and a variable speed drive, the power flow can be illustrated as in Fig. 3.

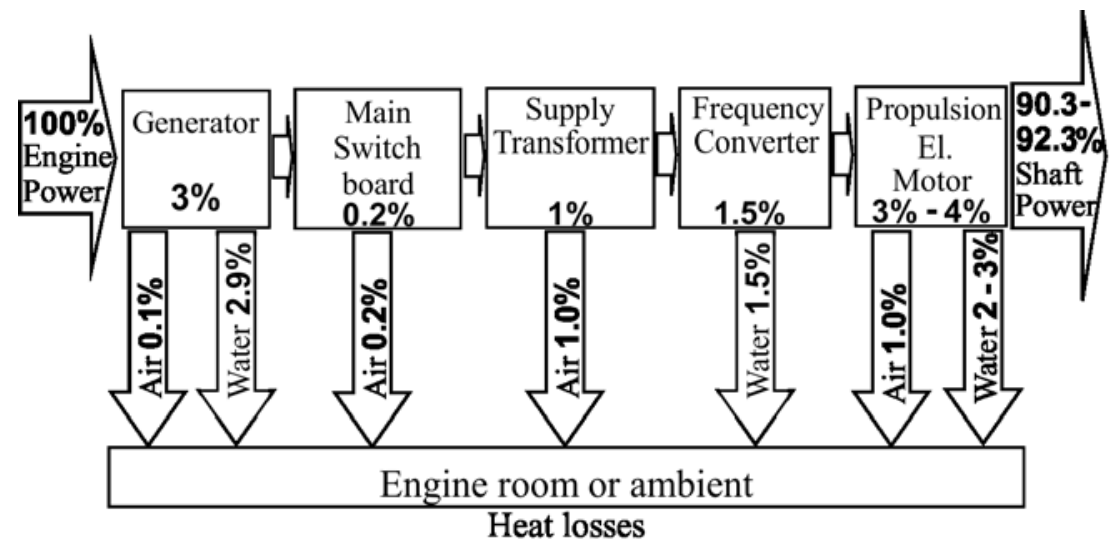

Fig. 3 Power losses in a simplified electric power system [12], [14]

The electrical efficiency of the system in Fig. 3 is:

$$
\eta=\frac{P_{\text {out }}}{P_{\text {in }}}=\frac{P_{\text {out }}}{P_{\text {out }}+P_{\text {losses }}}
$$

For each of the components, the electrical efficiency can be calculated, and typical values at full (rated) power ([12], [15], [16]) are for:

- Generator:

- Switchboard:

- Transformer:

- Frequency converter:

- Electric motor:

$$
\begin{aligned}
& \eta=0,95-0,97 \\
& \eta=0,999 \\
& \eta=0,99-0,995 \\
& \eta=0,98-0,99 \\
& \eta=0,95-0,97
\end{aligned}
$$


If electric propulsion is chosen, diesel electric propulsion system is still the most frequent shipowner's choice for different ship types. Orders of this system at the global level are visible in Table 2 for the year 2012 [17]. Table 2 provides an order review according to world's regions, which shows that the biggest customers of these propulsion systems come from the Far East and from Western Europe.

Table 2.: Diesel-electric marine propulsion orders for year 2012

\begin{tabular}{|c|c|c|c|c|c|c|c|c|c|c|c|}
\hline & esel-elect & ic mar & ne pro & ulsion & rders, J & nuary & $-\mathrm{De}$ & cembe & 201 & & \\
\hline \multirow{2}{*}{$\begin{array}{l}\text { Output } \\
\text { range } \\
\text { (MW) }\end{array}$} & \multirow[b]{2}{*}{$\begin{array}{l}\text { Number } \\
\text { of units }\end{array}$} & \multicolumn{2}{|c|}{$\begin{array}{c}\text { Engine } \\
\text { operating } \\
\text { speed ranges } \\
\left(\mathrm{min}^{-1}\right)\end{array}$} & \multicolumn{2}{|c|}{ Fuel } & \multicolumn{6}{|c|}{ Regior } \\
\hline & & $\begin{array}{c}< \\
1000\end{array}$ & $\begin{array}{c}> \\
1000\end{array}$ & $\begin{array}{c}\text { Diesel } \\
\text { fuel }\end{array}$ & $\begin{array}{c}\text { Heavy } \\
\text { fuel }\end{array}$ & 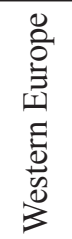 & 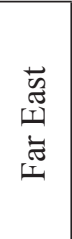 & 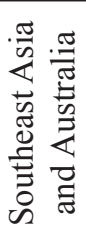 & 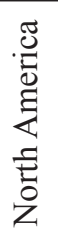 & 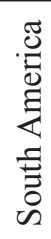 & $\frac{n}{0}$ \\
\hline $\begin{array}{c}1.01- \\
2.00\end{array}$ & 226 & 170 & 56 & 124 & 72 & 53 & 76 & 20 & 12 & 20 & 45 \\
\hline $\begin{array}{c}2.01- \\
3.50\end{array}$ & 272 & 150 & 122 & 208 & 64 & 115 & 51 & 25 & 56 & 4 & 21 \\
\hline $\begin{array}{c}3.51- \\
5.00\end{array}$ & 100 & 98 & 2 & 30 & 70 & 26 & 48 & 14 & 2 & 4 & 6 \\
\hline $\begin{array}{c}5.01- \\
7.50\end{array}$ & 182 & 182 & 0 & 138 & 44 & 4 & 104 & 12 & 0 & 0 & 20 \\
\hline$>7.50$ & 198 & 198 & 0 & 54 & 132 & 4 & 136 & 36 & 0 & 60 & 4 \\
\hline Totals & 978 & 798 & 180 & 554 & 382 & 202 & 415 & 107 & 70 & 88 & 96 \\
\hline
\end{tabular}

Today, diesel-electric propulsion systems can be divided into two areas, which are mainly used in operation of large cruise ships [18]:

a. Direct drive

b. Azipod drive

Examples of direct drive and Azipod systems layouts are given on Fig. 5 and Fig. 6. 


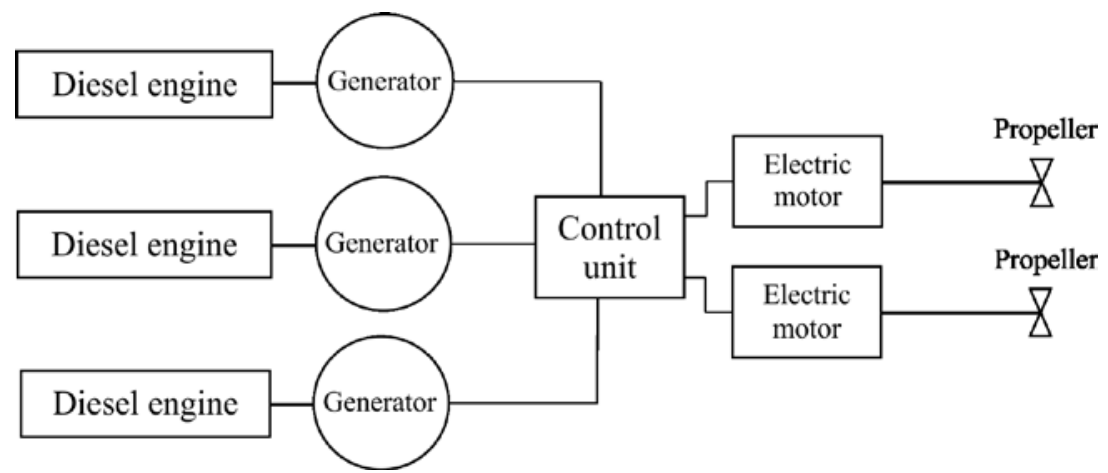

Fig. 5 Diesel-electric direct drive

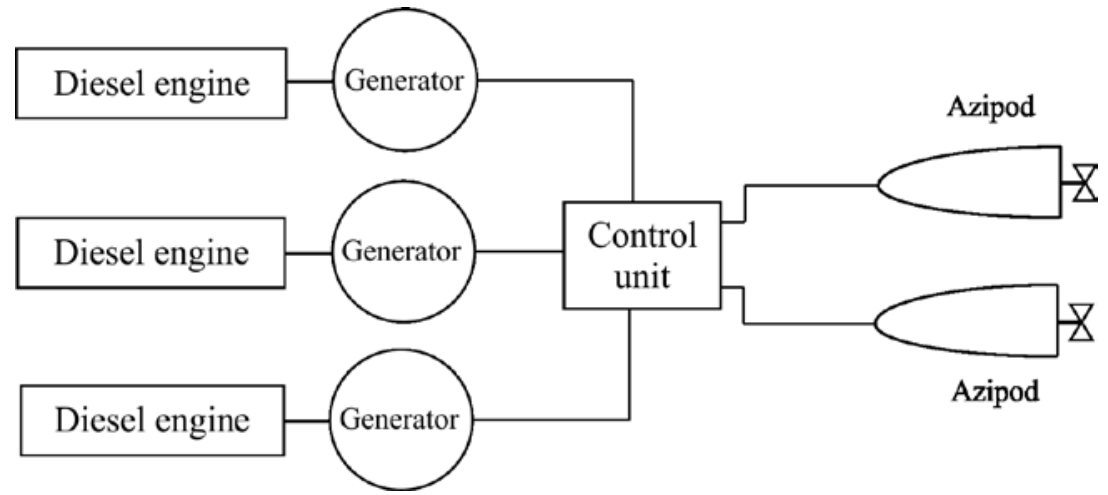

Fig. 6 Diesel-electric Azipod drive

Shipowners often choose Azipod propulsion because of higher operation flexibility, better ship manoeuvrability as well as the higher possible financial savings in ship's exploitation.

Presented systems of diesel-electric propulsion (Fig. 5 and Fig. 6) bring numerous benefits compared to diesel-mechanical propulsion systems, which can be seen primarily in the specific fuel consumption reduction, Fig. 7. 


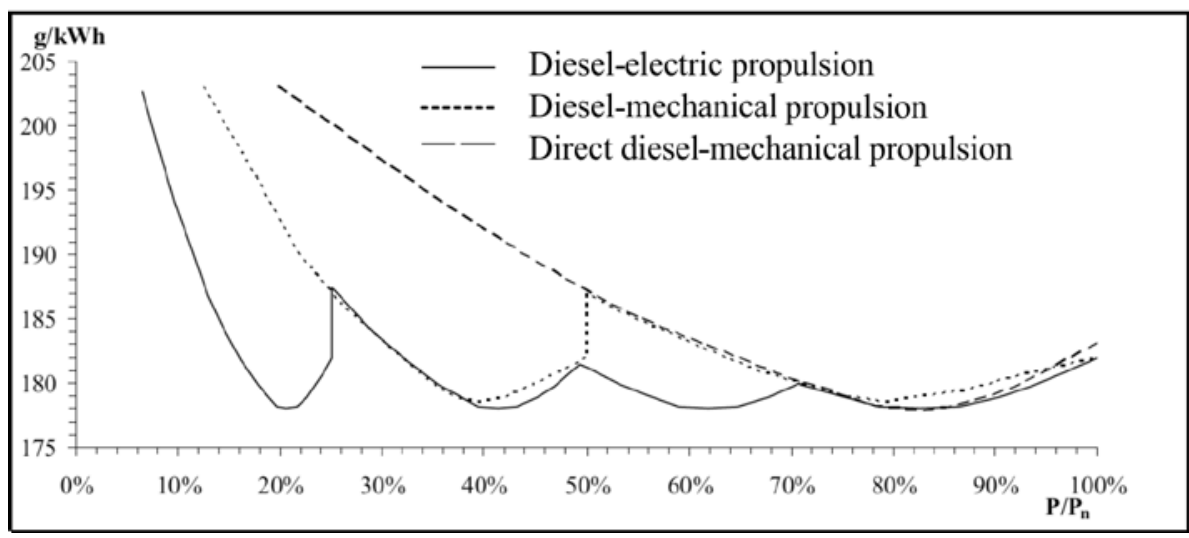

Fig. 7 Comparison of the specific fuel consumption depending on the total developed power on diesel engines shafts [15]

\section{Comparison of COGES and diesel-electric propulsion systems}

\subsection{Air pollutant emissions}

There are four principal air pollutants produced by prime movers which use fossil fuels: nitrogen oxides $\left(\mathrm{NO}_{\mathrm{x}}\right)$, sulfur oxides $\left(\mathrm{SO}_{\mathrm{x}}\right)$, carbon dioxide $\left(\mathrm{CO}_{2}\right)$ and particulates emission [19].

The production of $\mathrm{NO}_{\mathrm{x}}$ is unavoidable because of the nitrogen presence in atmospheric air. However, the quantity of $\mathrm{NO}_{\mathrm{x}}$ is a function of the fuel nitrogen content and a strong function of the combustion temperature in engine cylinders [20]. Higher temperatures result in more $\mathrm{NO}_{\mathrm{x}}$ and combustion of natural gas produces less $\mathrm{NO}_{\mathrm{x}}$ than combustion of HFO. Peak temperatures in diesel engines are significantly higher than in gas turbines so they produce more $\mathrm{NO}_{\mathrm{x}}$.

Production of $\mathrm{SO}_{\mathrm{x}}$ is governed by the fuel sulfur content. HFO typically contains significant amount of sulfur, but there is low sulfur HFO available at higher cost. Natural gas contains only a trace of sulfur so any engine burning natural gas produces very little $\mathrm{SO}_{\mathrm{x}}$.

$\mathrm{CO}_{2}$ production depends primarily on the ratio of hydrogen to carbon in the fuel and the efficiency of the propulsion system. Liquid fuels such as HFO and MDO have a ratio of hydrogen to carbon about 2:1 while methane, the dominant constituent in natural gas has a ratio of $4: 1$. As a result, combustion of liquid fuels produces significantly more $\mathrm{CO}_{2}$ than combustion of natural gas.

Particulates are primarily carbon particles or soot. The intermittent nature of diesel engine combustion is inclined to produce more particulates than the steady combustion in a gas turbine. 
Table 3 represents pollutant emissions from various propulsion systems where shown values are based on $\mathrm{kWh}$ of released heat.

Table 3.: Pollutant emissions comparison [19]

\begin{tabular}{|l|c|c|c|c|}
\hline \multicolumn{1}{|c|}{ Propulsion system } & $\begin{array}{c}\mathrm{NO}_{\mathrm{x}} \\
(\mathrm{g} / \mathrm{kWh})\end{array}$ & $\begin{array}{c}\mathrm{SO}_{\mathrm{x}} \\
(\mathrm{g} / \mathrm{kWh})\end{array}$ & $\begin{array}{c}\mathrm{CO}_{2} \\
(\mathrm{~g} / \mathrm{kWh})\end{array}$ & $\begin{array}{c}\text { Particulates } \\
(\mathrm{g} / \mathrm{kWh})\end{array}$ \\
\hline $\begin{array}{l}\text { Steam turbine } \\
\left(50 \% \text { BOG}^{*}, 50 \% \text { HFO* }\right)\end{array}$ & 1 & 11 & 950 & 2,5 \\
\hline $\begin{array}{l}\text { Slow-speed diesel } \\
(\text { HFO* with 2\% sulfur) }\end{array}$ & 17 & 7,7 & 580 & 0,5 \\
\hline Medium-speed diesel (BOG*) & 1,3 & 0,05 & 445 & 0,05 \\
\hline $\begin{array}{l}\text { Medium-speed diesel } \\
(\text { HFO* with 2\% sulfur) }\end{array}$ & 12 & 7,7 & 612 & 0,4 \\
\hline Medium-speed diesel (MDO*) & 12,5 & 2 & 620 & 0,04 \\
\hline COGES (BOG*) & 2,5 & 0 & 480 & 0,01 \\
\hline
\end{tabular}

*HFO = Heavy Fuel Oil; BOG = Boil Off Gas; MDO = Marine Diesel Oil

As Table 3 shows, a COGES plant is at or near the lowest value for each of the four emissions. Since COGES plants will be shown to have the highest cycle efficiency of the various alternatives, they look very attractive in terms of emissions production.

Fig. 8 shows that diesel-electric propulsion has lower $\mathrm{CO}_{2}$ emissions compared to COGES propulsion system but the other emissions are 6 to 11 times higher, which only confirms the advantage of COGES system in terms of emissions. Steam turbine in COGES system increases emissions, but not enough to be significantly closer to emissions from an internal combustion engine.

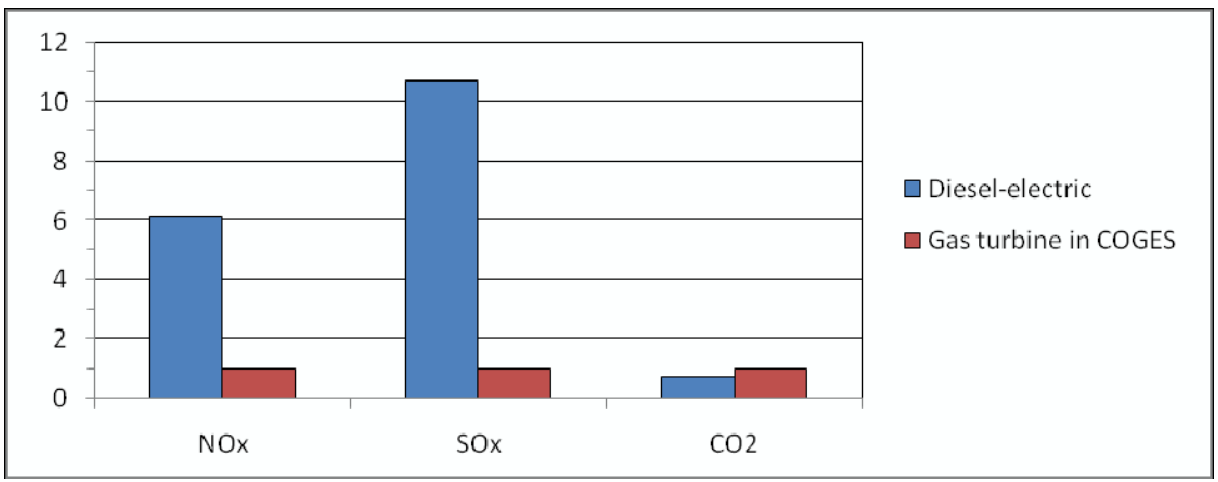

Fig. 8 Relative exhaust emission from different propulsion systems [13] 


\subsection{Weight and size}

Gas turbines are lighter and need less space than a diesel engine of the same power output [19], [7]. Diesel engine's size and weight are undisputable disadvantage in many applications. As regards the space savings of gas turbines, this potential cannot be fully utilized because gas turbines have approximately 15\% larger air intake and exhaust ducts as comparable diesel engines and their starting devices also occupy significant space [21].

\subsection{Relative investment costs for COGAS and diesel-electric propulsion systems}

Fig. 9 shows relative investment costs for various propulsion systems. COGES system would be slightly cheaper if installation costs were included. Compared with COGES, investment cost for diesel-electric propulsion system is almost half the price when engines run on HFO (Heavy Fuel Oil) or almost third the price when engines run on MDO (Marine Diesel Oil).

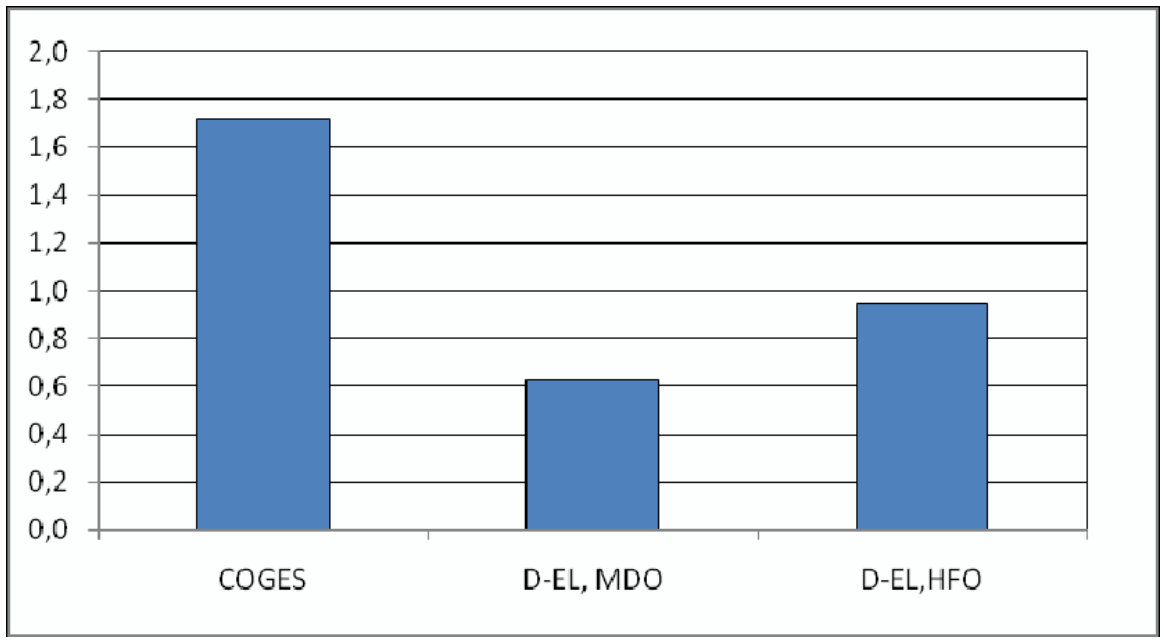

Fig. 9 Relative first cost for various propulsion systems [13]

\subsection{Maintenance costs}

Gas turbines represent the pinnacle of engineering in the quality of used materials, in the accuracy, precision and demanding processing procedures. Hence, all of these characteristics increase COGES maintenance costs compared to diesel engines [21]. The maintenance costs of diesel engines usually fall proportionally to the engine size, 
but in general, the costs of diesel engines maintenance are lower in comparison to COGES propulsion system of the same power output.

\subsection{Fuel consumption}

Diesel engines use significantly cheaper fuel compared to gas turbines. Very important fact is that specific fuel consumption of diesel engines is smaller in whole working range compared to gas turbines [10]. Efficiency of the COGES propulsion system decrease dramatically at low loads what results with significant increase in fuel consumption. Diesel engine's tolerance to load change is considerably better.

\subsection{Vibration and noise}

As regards vibration and noise, multiple cylinder reciprocating engines with their intermittent combustion are at a disadvantage. By direct-resilient mounting of diesel engines, their structure-borne vibration transmitted into a ship's foundation is reduced to a level of approximately $50 \mathrm{~dB}$ at frequencies of $1000 \mathrm{~Hz}$. Although resiliently seated gas turbines still might reach lower values.

Regardless of the type and number of silencers, diesel engine can not compete with gas turbines in this area. Air-borne engine room noise of gas turbines is claimed to be less than $85 \mathrm{~dB}$, whereas the noise emission of a large-bore medium-speed diesel engine varies between 102 and $108 \mathrm{~dB}$ at full load [10], [21].

\subsection{Lube-oil consumption}

The specific lube-oil consumption of modern gas turbines is typically only $1 \%$ of the diesel engine's figure, but high priced synthetic lubes have to be used in comparison to the low priced mineral oils for the diesel engines. The annual lube-oil costs of gas turbines are only about $6 \%$ of that for diesel engines [10], [21].

\subsection{Relative total annual cost for COGES and diesel-electric propulsion system}

Relative total annual costs (over 10 years) including investment, fuel and lubricating oil costs are shown on Fig. 10. It is also assumed that selective catalytic reduction (SCR) units are installed and run on diesel-electric propulsion systems. Relative total annual costs for diesel-electric propulsion systems are approximately $25-35 \%$ lower than the COGES system, regardless of whether diesel engines are running on HFO or MDO. 


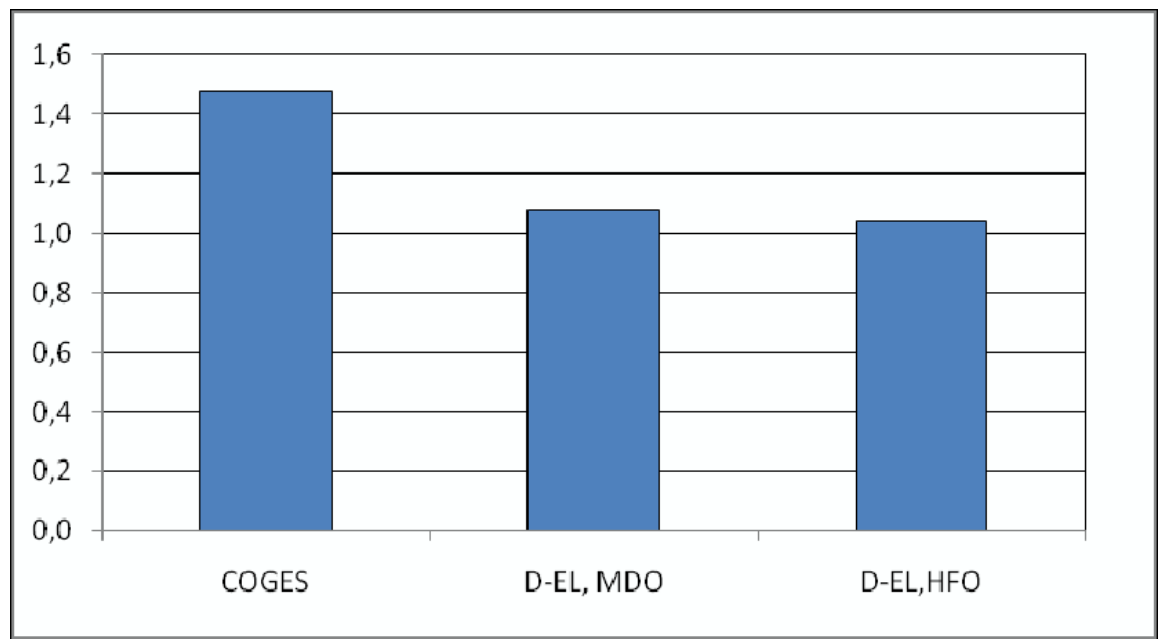

Fig. 10 Total relative annual cost for various propulsion systems [13]

\subsection{Overall performance comparison of COGES and diesel-electric propulsion systems}

The overall comparison performance of diesel-electric and COGES propulsion systems are shown in Table 4.

Table 4.: Overall performance comparisons of diesel-electric and COGES propulsion system

\begin{tabular}{|c|c|c|}
\hline & Diesel-electric & COGES \\
\hline Weight and size & & $(+)$ \\
\hline Investment costs & $(+)$ & \\
\hline Maintenance costs & $(+)$ & \\
\hline Fuel consumption & $(+)$ & \\
\hline The possibility of using HFO fuel & $(+)$ & \\
\hline Operation at part or low load & $(+)$ & \\
\hline The rate of operation mode change & $(+)$ & $(+)$ \\
\hline Vibration and noise & & $(+)$ \\
\hline Air-borne noise & & $(+)$ \\
\hline Lube-oil consumption & & $(+)$ \\
\hline $\mathrm{NO}_{\mathrm{x}}$ emission & & $(+)$ \\
\hline $\mathrm{SO}_{\mathrm{x}}$ emission & & \\
\hline $\mathrm{CO}_{2}$ emission & $(+)$ & \\
\hline Environmental conditions & $(+)$ & \\
\hline \multicolumn{2}{|l}{}
\end{tabular}




\section{COGES and diesel-electric propulsion for large cruise ship}

Diesel-electric propulsion system is installed in most modern large cruise ships because this system proved to be more acceptable and more economical.

Passenger vessels, cruise ships and ferries have high requirements for on-board comfort regarding noise and vibration [12]. Additionally, reliability and availability is very critical for the safety of the passengers and the vessel. Consequentially, electric propulsion was early evaluated to be beneficial and taken into use. The list of cruise vessels with electric propulsion is today long and increasing. As podded propulsion provides significant improvements in manoeuvrability, propulsion efficiency and fuel costs, a large and increasing number of new-buildings are specified with electrical podded propulsion.

When selecting gas-turbine based propulsion for a large cruise ship, it should be considered that [13]:

- Machinery is based on electric propulsion (as is almost standard today)

- Typical power demand varies from 8 - $9 \mathrm{MW}$ (in port) and around $50 \mathrm{MW}$ (at sea)

- Hotel services need a lot of heat for fresh water production. Heat demand (steam) is typically $25-28$ tones/h

- The operational power consumption profile is not constant and includes several power levels. The machinery choice has to be based on an annual energy profile (power by time) where Fig. 12 shows a typical example when $75 \%$ of the energy is consumed at below 20 knots.

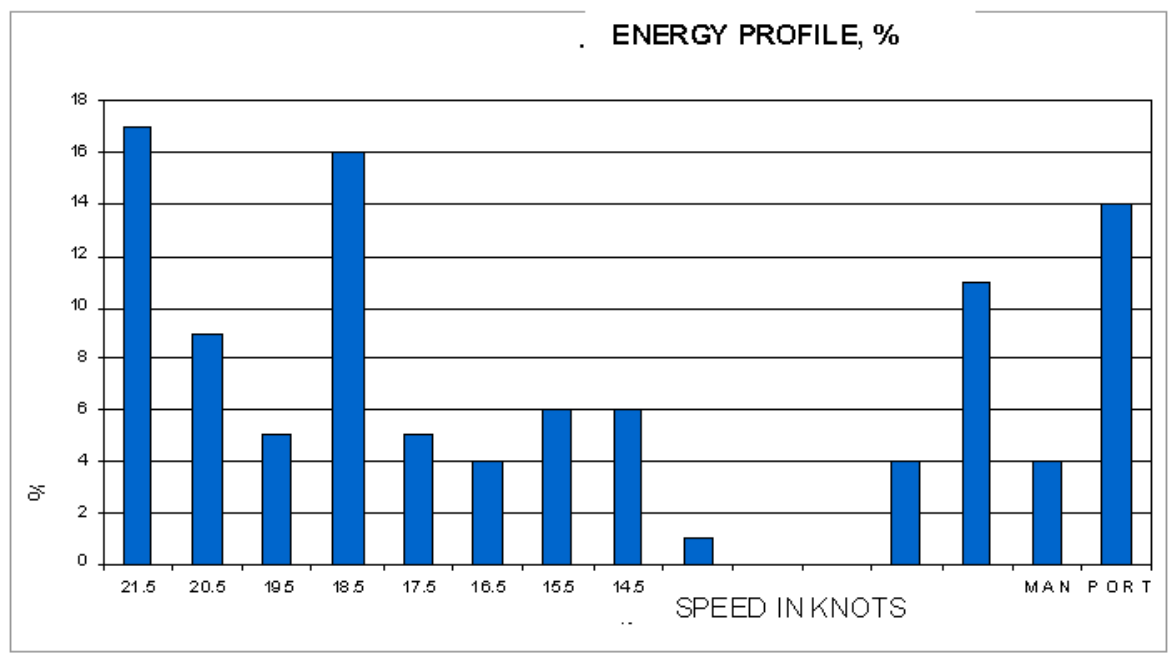

Fig. 12 A typical large cruise ship speed profile [13] 


\subsection{Case study of COGES propulsion system installed on large cruise ship}

Cruiser Millennium is one of the few cruise ships which do not use diesel-electric propulsion, but COGES propulsion system. COGES system of this cruiser ship consists of two General Electric gas turbines, $25 \mathrm{MW}$ each, and one steam turbine with power of $8 \mathrm{MW}$. COGES propulsion system generates enough electricity to drive two RollsRoyce/Alstom Mermaid azimuth thrusters (with power of 19 MW each). COGES system is designed in a manner that the gas turbines are main propulsion devices, and the steam turbine is used to produce additional electricity. The steam for the steam turbine operation is obtained from the gas turbines exhaust gas steam generator. Depending on the amount of steam required for the electricity production, the entire COGES propulsion system has efficiency between 45 and 50\%. Electricity produced with steam turbine is used for a variety of ship services: for additional drive of azimuth thrusters, for heating and cooling throughout the ship, and finally for ship lighting and ventilation. Also, the electricity generated by steam turbine fully supplies the ship's main galley and laundry.

\subsection{Exploitation costs of COGES propulsion system compared to equivalent diesel-electric propulsion system for large cruise ship Millennium}

Diesel-electric propulsion system could be a major competitor to COGES system when shipowner chooses a propulsion system. COGES propulsion plant installed on cruiser Millennium, with the total power output of $58 \mathrm{MW}_{\mathrm{el}}$ is compared with dieselelectric propulsion plant which consists of five medium-speed diesel engines (and the corresponding generators and electric motors) with total power output of $61 \mathrm{MW}_{\mathrm{el}}$. To compare these two systems, it is necessary to take into consideration the annual fuel costs.

The calculation of annual fuel cost is based on a typical weekly load scenario of 60 hours per week in ports (power requirement $10 \mathrm{MW}_{\mathrm{el}}$ ) with one medium-speed diesel engine or one gas turbine with a steam turbine in operation [21]. This scenario includes 3840 working hours per year for each of the five diesel engine or 6150 hours for each of the two gas turbines. For this scenario, the annual fuel costs have been calculated at average prices of marine fuel markets of north-western Europe for year 2000 and obtained values are given in Table 5. 
Table 5.: Annual fuel costs for COGES and diesel-electric propulsion systems (for year 2000)

\begin{tabular}{|l|c|c|}
\hline $\begin{array}{l}\text { Annual costs for COGES (58 MW) and diesel-electric } \\
\text { propulsion system (61 MW) in million US \$ }\end{array}$ & COGES & Diesel-electric \\
\hline Fuel & MGO & HFO 380 cSt \\
\hline Fuel price, US \$ per ton & 300 & 145 \\
\hline Fuel consumption, ton & 45120 & 39540 \\
\hline Annual fuel cost, million US \$ & 13,54 & 5,73 \\
\hline Additional fuel for steam production (17 tonnes/h), tone & 1000 & 7050 \\
\hline Additional fuel cost, million US \$ & 0,3 & 1,03 \\
\hline Total annual fuel cost, million US \$ & 13,84 & 6,76 \\
\hline
\end{tabular}

According to the fuel price at the moment when cruiser Millennium was launched, the difference in annual fuel costs between COGES and diesel-electric propulsion system was 7 million US \$. Cost of extra fuel used in boilers for steam production is also included in Table 5. COGES system needs very little extra fuel for steam production, while diesel-electric system consumes more fuel for the production of the same quantity of the steam.

The fundamental question is whether much higher fuel costs of COGES system in relation to the same power diesel-electric system can be compensated with higher income of 50 additional double-passenger cabins on lower decks of cruiser Millennium (additional cabins are built because chosen propulsion system brought savings to the ship's space). This question arises after the statement of the shipowner that the additional passenger cabins will justify higher fuel costs of COGES propulsion system.

If it is assumed that $90 \%$ of capacities in 50 additional cabins are continuously sold out 50 weeks a year and if it is taken the real price of accommodation of about 200 US $\$$ per person per day, income from additional cabins will be approximately 7 million US \$ annually. The net profit of 7 million US \$ income is approximately $30 \%$ or 2,1 million US \$. The remaining $70 \%$ are cost to build and equip the cabins, cost of food, staff, cabins cleaning, laundry, taxes, etc.

The difference in fuel cost of COGAS system in comparison to diesel-electric propulsion system cannot be compensated with additional 50 passenger cabins. If calculated difference in annual fuel costs of 7 million US \$ in favour to diesel-electric system is reduced with the net annual profit of 50 additional passenger cabins, which is 2,1 million US $\$$, the difference of 4,9 million US $\$$ by a year remains irretrievably lost due to this selection of propulsion system. This conclusion is carried out for conditions and prices in fuel market in the year when ship Millennium was launched. As far as fuel prices has changed extremely in past 15 years, the same operating costs calculation for these propulsion systems was performed for year 2015. According to the stock market of marine fuel in Rotterdam on the November $6^{\text {th }} 2015$ [22], the fuel prices were 418 US \$ per ton for MGO and 217 US \$ per ton for HFO. 
Calculation of analyzed propulsion systems costs is performed with the same presumptions from previous example for year 2000 and obtained results are given in Table 6.

Table 6.: Annual fuel costs for COGES and diesel-electric propulsion systems (for year 2015)

\begin{tabular}{|l|c|c|}
\hline $\begin{array}{l}\text { Annual costs for COGES (58 MW) and diesel-electric } \\
\text { propulsion system (61 MW) in million US \$ }\end{array}$ & COGES & Diesel-electric \\
\hline Fuel & MGO & HFO 380 cSt \\
\hline Fuel price, US \$ per ton & 418 & 217 \\
\hline Fuel consumption, ton & 45120 & 39540 \\
\hline Annual fuel costs, million US \$ & 18,86 & 8,58 \\
\hline Additional fuel for steam production (17 tones/h), tone & 1000 & 7050 \\
\hline Additional fuel costs, million US \$ & 0,42 & 1,53 \\
\hline Total annual fuel costs, million US \$ & 19,28 & 10,11 \\
\hline
\end{tabular}

In year 2015, the difference exploitation costs increases in favour of diesel-electric propulsion and now figures 9,17 million US \$. Prices of additional passenger cabins have not significantly changed so shipowners net profit can be presumed 2,1 million US \$, the same as for year 2000. Therefore, due to the selection of COGES propulsion system, shipowner irretrievably lost over 7 million US \$ of net profit in year 2015.

\section{Conclusion}

This paper presents a comparison of diesel-electric and alternative COGES propulsion system. Due to lower exploitation costs, diesel-electric propulsion system remains the primary choice for the majority of shipowners. On the other hand, the exploitation costs of COGES propulsion system are much higher. It is also shown that additional passenger cabins built on ship with COGES propulsion system cannot compensate the difference in costs of these two systems. The performance characteristics of these systems show that neither has a distinct advantage over the other. The only aspect where COGES propulsion system has a significant advantage is emissions of pollutants into the environment. COGES propulsion system could become very interesting in the future if the emission regulations become more rigorous. 


\section{References}

1. Haglind, F.: A review on the use of gas and steam turbine combined cycles as prime movers for large ships. Part I: Previous work and implications, Energy Conversion and Management, 49 (2008), pp. 3468-3475

2. Mills, R. G.: Greater ship capability with combined-cycle machinery, Naval Engineers Journal, 89, pp. 17-25, 1977.

3. Brady, E. F.: Energy conservation for propulsion of naval vessels, Naval Engineers Journal, 93, pp. 131-144, 1981.

4. Halkola, J. T., Campbell, A. H., Jung, D.: RACER Conceptual Design, J. Eng. Power 105(3), 621-626, 1983.

5. Ahlqvist, I.: Increasing availability through introduction of redundancy-electric propulsion, The Institute of Marine Engineers, 5-6 October 1995.

6. Shipping World and Shipbuilder, Gas turbine system integration, Ship World Shipbuild, pp. 203-213., 2002.

7. Royal Academy of Engineering: Future ship powering options - Exploring alternative methods of ship propulsion, Report, July 2013.

8. McKesson, C. B.: Alternative powering for merchant ships, Center for the Commercial Deployment of Transportation Technologies, 2002.

9. Dzida, M., Olszewski, W.: Comparing combined gas turbine/steam turbine and marine low speed piston engine/steam turbine systems in naval applications, Polish maritime research, 4(71), Vol 18; pp. 43-48., 2011.

10. Konstantinos A.: Techno-economic Evaluation of Various Energy Systems for LNG Carriers, National Technical University of Athens, Diploma Thesis, July, 2006.

11. Cwilewicz, R., Górski, Z.: Prognosis of marine propulsion plants development in view of new requirements concerning marine fuels, Journal of KONES Powertrain and Transport, Vol. 21, No. 2, 2014.

12. Kåre Ådnanes, A.: Maritime Electrical Installations And Diesel Electric Propulsion, ABB Marine, Technical brochure, 2003.

13. The Royal Institution of Naval Architects: The future of ship design Part 2, Deltamarin Ltd., June 2001.

14. Balashov, S.: Design of marine generators for alternative diesel-electric power systems, Lappeenranta University of Technology, Master of Science Thesis, 2011.

15. Vučetić, D., Čekada, I.: Eksploatacijske prednosti električne propulzije, Pomorstvo, godina 20, br. 1, str. $129-145,2006$.

16. Herdzik, J.: Problems of propulsion systems and main engine choice for offshore support vessels, Scientific Journals 36(108), 2013.

17. Haight, B.: 2013 Marine Propulsion Order Survey, Diesel and Gas Turbine Worldwide, JulyAugust, 2013.

18. ABB System project guide for passenger vessels, Helsinki, Finland, February 2011.

19. Wiggins, E. G.: COGAS Propulsion for LNG Ships, Journal of Marine Science and Application 10, 175-183, 2011.

20. Senčić, T.: Analiza mogućnosti smanjenja emisija čađe i NO $O_{x}$ a suvremenim sporohodnim dizelskim dvotaktnim motorima (Analisys of soot and $N O_{x}$ emissions reduction possibilities on modern low speed, two stroke, diesel engines, in croatian), Doctoral Thesis, University of Rijeka, Rijeka, 2010.

21. Koehler, H. W.: Diesel Engines and Gas Turbines in Cruise Vessel Propulsion, Presentation at The Institution of Diesel and Gas Turbine Engineers, London, February, 2000.

22. http://www.bunkerworld.com/prices/ (last visited 06.11.2015.) 
Vedran Mrzljak, Tomislav Mrakovčić

\section{Usporedba COGES i dizel-električnog propulzijskog sustava broda}

\section{Sažetak}

Dizel-električna propulzija broda u današnje je vrijeme čest odabir brodovlasnika, pogotovo ukoliko je riječ o putničkim brodovima. No, uz brojne prednosti, primarni nedostatak dizelskih motora je njihova emisija štetnih tvari u okoliš. Kako su ekološki standardni sve stroži, postavlja se pitanje optimalne alternative dizel-električnoj propulziji. Jedan od prijedloga alternativne propulzije je sustav kombinirane propulzije COGES (COmbined Gas and Steam Electric), primarno zbog smanjenja emisija štetnih tvari u okoliš. No isto tako, neke analize ukazuju da COGES sustav propulzije može biti i isplativiji u odnosu na dizel-električnu propulziju, poglavito kod putničkih brodova gdje bi se viša početna investicija nadoknadila povećanjem broja putničkih kabina. Ovaj rad prikazuje usporedbu navedenih sustava propulzije, koja može biti korisna za pravilan odabir optimalnog propulzijskog sustava broda.

Ključne riječi: COGES, Dizel-električna propulzija, Emisija štetnih tvari 